\title{
Garbhavkranti and Chronological Evaluation of Garbha: A Review
}

\author{
Kannan Mani ${ }^{1}$, Sheetal A. Agrawal ${ }^{2}$, Ashish S. Agrawal ${ }^{3}$ \\ ${ }^{1}$ Professor \& HOD, Rachana Sharir Dept, Jupiter Ayurved Medical College and Tarini Ayurved Hospital, \\ Shankarpur Nagpur \\ ${ }^{2} \mathrm{MD}$, Rasashastra \& Bhaishajyakalpana, Nagpur \\ ${ }^{3}$ Professor \& HOD, Sharir Kriya Dept, Smt. Vimladevi Ayurved Medical College, Chandrapur
}

Corresponding Author: Sheetal A. Agrawal

\begin{abstract}
Ayurveda the science of medicine deals with the aim of Swastha Sharir. The Rachna Sharir is the ayurveda term which mainly deals with the anatomical and physiological compositions of body. Sushrut samhita is one of those Ayurvedic classic which deals with human anatomy and physiology. It gives precise description of Garbha vruddhi and vikas kram in detail. The knowledge of Sharir starts from Garbha. The understanding of Garbha helps to manage healthy progeny.

According to Ayurveda, the union of shukra (spermatozoa), shonita (ovum) and Atma (soul) inside the uterus is known as garbha (embryo). The fertilization between Shukra and Shonita produces zygote which further develops into fetus. The Ritu, Kshetra and Ambu etc. plays vital role in the proper development of fetus.. Different components originating from Five Elements takes part in the formation, development of the garbha. The whole process of development of the foetus from two cells to mature foetus is called Garbhavakranti. It includes the basis of the earliest embryology which was known to the human being. In Ayurvedic texts the process of chronological development of the foetus is explained clearly. The understanding of Garbha development helps to acquire necessary conditions which required for the better management of pregnancy. Extensive study and discussion is essential to understand ancient concept of Garbha vikas kram. Review of Ayurvedic text along with modern text will help to obtain knowledge regarding this. This study is an
\end{abstract}

attempt to elaborate and compare both ancient and modern concept of foetal development.

Keywords: Shukra, Shonit, Garbha, Garbhavakranti, Garbha vikas kram.

\section{INTRODUCTION}

Foundation of Ayurveda Science is based on the ancient philosophies which are fundamental sciences of the ancient Indian think tank. Ancient scholars have enumerated a number of factors, which together lay the physiological and physical make-up of an individual. In Sharirsthana Acharya Sushrut has elaborated process of Garbha utpatti. He has explained characteristics of Shuddha i.e. normal Shukra (semen) and Artav (menstrual flow). Garbhavkranti is the word which literally means descent of the soul into the womb. ${ }^{[1]}$

There is systematic description of foetal development which starts from Shukra-shonit sanyog i.e., fertilization. Our Acharayas has done lot of research work on garbha sharir and its chronological month wise development during antenatal period. Nowadays Advanced imaging and diagnostic techniques facilitate assessment of foetal growth and development. So it is very easy now to understand ongoing events inside uterus during antenatal period. It would be helpful to assess resemblance in Ayurvedic and modern medical viewpoint. 


\section{MATERIAL AND METHODS}

Ayurvedic Samhita and their commentaries, modern medical text books and published research papers, Articles, Medical journals and Internet

\section{Type of study: Literary review study}

\section{Qualities of Shukra and Artava}

Shukra (Semen) has the quality of being white like soma and Artava is red like fire. All elements are also present in them in minute degrees. These elements have the natural attribute of helping and strengthening each other and intermingling with them. ${ }^{[2]}$ Just as a ball of ghee melts when placed near a fire similarly the female seed is set forth in coition with man. ${ }^{[3]}$

\section{Gharbhavakrati}

Garbhavakranti comprises of two words, i.e., the „Garbha and „Avakranti" which literally gives an idea about descent of a dormant embodied life principle. In ancient literature of Ayurveda "Garbhavkranti Shariram" is the science which deals with all these phenomenon. Veda, Purana, vrihatrayi, Laghutrayi, Commentators of samhitas specially Dalhan, chakrapani, Arundatta etc also has illustrated garbhavkranti-Shariram. It can be divided into three parts so that the gradual development and formation can be studied easily.

(1) Garbha Avataran (Inception)

(2) Garbha Nirman (Formation)

(3) Garbha Poshana (Nourishment

According to Indu; the commentator of Astanga Sangraha, Vayu releases during copulation, the Tejas energy of the body and this uniting with Vayu, ejects semen. This enters the female passage and combines with Artava. The embryo which develops from this is thus a combination of Soma and Agni and lodges in the uterus. ${ }^{[4]}$ It is only when Jiva descends in this combination of Shukra and Artava that a foetus begins to form. ${ }^{[5]}$ Jiva is called Kshetrajna and owing to its predestined union with the gross elements and the three qualities i.e. Sattva, Rajas and Tamas, it becomes endowed with a character wholly divine or partly so; or demonic and impelled by Vayu, enters the uterus and stays there. ${ }^{[6]}$

Samyoga of Shukra, Shonita and Jeeva inside the Kukshi is termed as Garbha. The intercourse between male and female involve Shukrachyuti, Shukra moved towards Yoni through Vata and deposits in Garbhashaya. Combination of these Shukra along with Shuddhartava forms Garbha. The fertilized ovum gets implanted in the endometrium with formation of germ layer. Aahar Rasa comes from mother help Garbha to grow. The proper formation and development of Garbha depends upon the quality of Shukra, Shonita and Ritu Shadbhavas, Garbhiniparicharya, proper diet by the mother during Garbhavastha, Upasneha, Upasveda, Kala and Swabhava samsiddhi play important role in the feotal growth. Satva \& Atma are some factors also essential for the development of Garbha. Shadbhava are the factors responsible for the formation of foetus which also described by modern science such as; maternal, paternal, environmental and nutritional.

Vayu, Teja, Apa, Prithvi and Akash are responsible for the stabilized structural development of body parts. Mahabhuta helps in stimulating secretion of hormones, separation of cell mass and influences transport of nutrients through umbilical cord. ${ }^{[7-9]}$

Garbha is the coalescence of the male and female seeds in the uterus where the soul combines with them intimately along with the eight Prakriti (elementary principles) and sixteen Vikaras i.e. formation of Prakriti. ${ }^{[10]}$ The embryo is staled a body only when it is thus developed with hands, feet, tongue, nose, ears, buttocks and other organs. ${ }^{[11]}$

\section{Chronological Month Wise Development Of Foetus}

In modern science, the developmental anatomy is studied is the branch named as "Embryology". 
Embryology is the study of the embryo/foetus from the moment of its inception upto the time when it is born an infant.

\section{Intrauterine life of foetus can be divided into}

(1).Ovum stage - From fertilization to end of 1 st week.

(2).Embryo stage - From second to Eighth week

(3).Foetus stage - From third month to birth.

The most elaborate and accurate description of the initial stage of development of garbha which resembles most to the modern embryological concepts is mentioned in Haarit Samhita.

Charaka opinions that in the first month, atma gets mixed up or vitiated by all the dhatus (tissue) and attains a mucoid appearance. Previously due to prithvi tattva, the shape is solid Sushruta and vagbhata are of the opinion that during the first month, the embryo is in shape of Kalala. ${ }^{[12]}$ As per garbhupnishad the fertilized egg becomes Kalala in one night, budbuhda in 7 nights, pinda in 15 days and solid in one month. ${ }^{[13]}$

Yajnavallkya Smriti has said that after union of Shukra and Shonita along with panchmahabhuta as well as descent of atma all these gets mixed up and are moistened in first month ${ }^{[14]}$ Sankledabhut ${ }^{\text {ee }}$ Harita has elaborated the views of Yajnavalkya and said that after union of Sukra and shonita on the first day, it attains the form of Kalala, On the 10th day it becomes budbuda, on 15rh day a solid and on 20th day a mass of flesh. The Panchmahabutas gets associated with it on 25 th day and by the end of one month all the tatavas become conspicuous. ${ }^{[15]}$

\section{Masanumasik Krama According to Acharaya Shushruta ${ }^{[16]}$}

First month- According to Ayurvedic scholars, during the first seven days Kalal is formed which is semisolid, slimy and sticky in nature. The fertilized ovum becomes Kalal and Budbuda.
Second month- In this month Sheeta, Ushma and Anila,guna help to turn, the Panchabhautik embryo into a compact mass called as Ghana. Garbha takes a compact form in the shape of a Pinda, Peshi or Arbuda which helps in identification of the gender. The Pinda shaped Garbha leads to the production of a Pumaan child, the Peshi shaped Garbha produces Stree child and Arbuda shaped Garbha produces Napunsak child.

Third month- In the third month Sarva Indriya, Sarva Angavayava manifests them simultaneously. Five buds (Pindaka) develop representing the formation of four limbs and head respectively. The AngaPratyanga begins to form but all are in very minute form. Development of heart and all the sense organs also starts.

Fourth month - In the fourth month Garbha becomes stable and dense. Due to the increase in mass, pregnant lady feel the heaviness in body. Anga, Pratyang are more prominently developed. The Sukshma forms of all body parts acquire certain form and shape. The Chetana Dhatu also gets manifested because the Hridaya becomes evident and due to this Garbha starts movements and responds to sensory stimuli.

Fifth month- In the fifth month mind becomes well active due to increased Mansa and Shonita during the fifth month. The Mana of fetus becomes more Sajiva. The blood and muscle tissue of the Garbha increases.

Sixth month- In the sixth month the development of intellect or Buddhi occurs. Development of tendons, veins, hair on the body and head, strength, colour, nails and skin occur. There is increase in Bala and Varna of the Garbha during this period.

Seven month- In the seventh month there is an all-round development of the Garbha occurs. Differentiation of all the AngaPratyangas becomes clearer. Garbha attains well developed mental and and physical form

Eighth month- In the eighth month of pregnancy, life is fatal for Garbha and Garbhini. Ojas travel between the mother 
and the child alternately through placenta and umbilical cord. Ojas are considered to be the purest form of all Dhatus, which decide the vitality, immunity and strength of the body and without it life becomes unstable.

Ninth month- In this month full growth of foetus is completed. In Ayurveda Samhitas normal gestational period is said to be 9 to 12 months. After this period if Garbha still remains in the uterus, it is called as Garbhavikriti.

\section{Growth Of Foetus According to Modern view \\ FIRST MONTH}

Modern obstetrics states that at the end of first month, a fertilised egg grows within a amniotic sac. Development of placenta takes place which has nutritive and excretory functions. [17] In process of embryogenesis, after fertilisation, development of morula takes place from embryoblast. Morula contains multicellular mass and fluid. Some fluid passes into the morula from the uterine cavity. As quantity of fluid increases, the morula acquires the shape of cyst. As pregnancy continues morula get transformed into blastocyst. Blastocyst gives rise to three germ layers1). Endoderm 2). Ectoderm 3). Mesoderm. All tissues of the body are derived from one or more of these layers. ${ }^{[18]}$

\section{SECOND MONTH}

At sixth week, baby's heart begin to separate into four chambers and it beats about 150 times in a minute. Embryo has comparatively large head than trunk. [19] Central nervous system, sensory organs and digestive system start to develop. [17] Branching of nerve cells in foetal brain results into formation of early neural pathways. Although it is not possible to confirm gender of foetus by ultrasound until after 15 weeks, his genitals begin to form at 9th week. ${ }^{[19]}$

\section{THIRD MONTH}

During 8-12 th week centres of ossification appear. Fingers and toes get differentiated. Development of skin, nails and hairs takes place. Variation in external genitalia begins. ${ }^{[20]}$

\section{FOURTH MONTH}

During 12-16 weeks eye movements begin which indicates maturation of midbrain. ${ }^{[20]}$ The part of foetal brain responsible for complex thoughts, such as problem solving and memory starts to form at 13 th week. ${ }^{[19]}$ Determination of foetal sex is possible as external genitalia show definitive signs of male or female. ${ }^{[20]}$ Total weight gain during the course of singleton pregnancy for a healthy women averages 11 $\mathrm{kg}$. Major weight gain occurs during second and third trimester which is around $5 \mathrm{~kg}$ in each. ${ }^{[21]}$

\section{FIFTH MONTH}

During 16-20 weeks maturation of cochlear function begins so foetus can respond to sound. ${ }^{[20]}$ At 19 th week foetal brain start to form separate areas which are specialized for sense of smell, test, hearing, vision and touch. ${ }^{[19]}$

\section{SIXTH MONTH}

During 20-24 weeks eyebrows and eyelashes become recognizable. Lung development almost completed. A foetus born at this time will die due to absence of terminal sacs. Development of neural pain system take place. ${ }^{[20]}$

\section{SEVENTH MONTH}

During 24-28 weeks skin become red and get covered with vernix caseosa. Foetus show isolated eye blinking. [20] Production of blood cells start at bone marrow at seventh month. It take place in liver and spleen before seventh month. ${ }^{[19]}$

\section{EIGHTH MONTH}

During 28-32 weeks Brain become more complex. Bones continue to harden. Skin become more smooth. ${ }^{[18]}$ Most 
internal systems are well developed.

[17] Final trimester of pregnancy can bring about stressful emotions and mood swings. Hormone levels change during pregnancy which affects brain chemicals in charge of regulating moods. The first and third trimesters are the most common times for irritability and issues of mood swing. ${ }^{[22]}$

\section{NINTH MONTH}

During 32-36 weeks pregnancy is considered as full term. Foetus swallow lanugos hairs and vernix caseosa which result into meconium after birth. ${ }^{[19]}$

\section{DISSCUSSION}

In Sharirsthana Acharya Sushrut has elaborated process of Garbha utpatti. He has explained characteristics of Shuddha i.e. normal Shukra (semen) and Artav (menstrual flow). Garbhavkranti is the word which literally means descent of the soul into the womb. ${ }^{[1]}$, the union of shukra (spermatozoa), shonita (ovum) and Atma (soul) inside the uterus is known as garbha (embryo). The fertilization between Shukra and Shonita produces zygote which further develops into fetus. The Ritu, Kshetra and $A m b u$ etc plays vital role in the proper development of foetus. Different components originating from five elements takes part in the formation, development of the garbha. The whole process of development of the foetus from two cells to mature foetus is called Garbhavakranti.

In the beginning the foetus obtains its nourishment from rasa which is supplied by mother. That clearly means nourishment and development of the foetus depends upon all the Shadbhava (six factors of conception). Ayurvedic Acharya mentioned six procreative factors (shadgarbhakarabhavas) which have an important impact on the process of fertilization and development of the foetus.

Ayurveda has explained month wise foetal development comprehensively, with its own principles. It is interesting fact that the details regarding month wise foetal development were noted in a period when equipments, technology of the modern science were not present. As in the first month it is a stage of kalalam or bubbuda awastha As in the second and third month of foetal development, stability of the foetus is important or it becomes comparatively more stable, the pregnant woman should involve herself in gentle activities for relaxation and calmness. The division into the five pinda take place by akasha mahabhuta. In 8-9 weeks of foetal development sonographic study reveals that limb bud appear, Head can be seen as separate from the body. Describing the development of the foetus in the fourth month the shape and all the parts of the body is almost formed. As per the modern science palpation of the foetal body parts can be made. Foetal movements can be felt by placing the hand over uterus. Sushruta called the pregnant woman as dauhridini (with two hearts).Cravings of the pregnant woman should get fulfilled during this period. In the sixth month, Foetus acquires well developed form in physical and mental aspect. Mother looks radiant. The skin of the foetus becomes reddish and wrinkled due to the lack of underlying connective tissue. In the seventh month, the testies descend downwards. A foetus born during this period (i.e. sixth or the early seventh month) has survived with great care. In the eighth month, Deposition of fat under the skin and wrinkles disappear. As per modern science skin becomes stretched and tight due to the more deposition of underlying fat. If the birth of a child takes place in this month, it is very difficult to survive. Considering each month of foetal development as per Ayurveda, many facts that Ayurveda scholars have described in their samhitas are found to be true on the basis of sonographic studies.

\section{CONCLUSION}

Ayurvedic embryology explains month wise foetal development along with the antenatal care of the pregnant woman which is found to be true on the basis of modern science. As we observe both 
viewpoints, there are some prominent similarities between Ayurvedic garbha vikas and modern foetal development. Though there were no advanced techniques, Acharyas have described a detail of foetal development which is appropriate in this era also. Every day, there are discoveries of new facts. So my work is a pathway for future research which intend to verify old facts with modern tools. Mother supplies the seed (ovum), bhumi (uterus) as well as nutrition through blood (rasaja and sattvaja bhava) to foetus so ayurved gives utmost importance to mother's physical and mental health. If we can understand their line of thinking and follow their path we will be able to understand Ayurveda thoroughly and go ahead following their footprints.

\section{Acknowledgement: None}

\section{Conflict of Interest: None}

\section{Source of Funding: None}

\section{REFERENCES}

1. Vaman Shivram Aapte, The student's Sanskrit-English dictionary, First edition, Bharatiya Granth Niketan, New Delhi, 2011, page no. 183

2. Acharya YT. Shushruta, Sushruta Samhita, Sharirasthana, 3/7, 7th ed. Varanasi: Chaukhambha Orientalia; 2002. p. 352.

3. Acharya YT. Shushruta, Sushruta Samhita, Sharirasthana, 2/80, 7th ed. Varanasi: Chaukhambha Orientalia; 2002. p. 350 .

4. Acharya YT. Shushruta, Sushruta Samhita, Sharirasthana, 3/19, 7th ed. Varanasi: Chaukhambha Orientalia; 2002. p. 362.

5. Acharya YT. Charaka. Charaka Samhita, Sharirasthana, 3/24, 7th ed. Varanasi: Chaukhambha Orientalia; 2002. p. 315.

6. Acharya YT. Shushruta, Sushruta Samhita, Sharirasthana, 3/53, 7th ed. Varanasi: Chaukhambha Orientalia; 2002. p. 360.

7. Charaka Samhita of Agnivesha, revised by Charaka \& supplemented by Dridhabala with Ayurveda Dipika commentary by Chakrapanidutta. (ch.sha.4/5).

8. Kaviraja Ambikadutta Shastri, Sharirstan: 2nd Shukrashonitshuddhi, 3rd Garbhav krantisharir, SushrutSamhita, Twelth edition, New Delhi, Chaukhamba.

9. Prof. Premvati Tewari, 2nd part Garbhdhan Vidhi, Ayurvediya Prasutitantra Evam Striroga, 2nd Edition, Varanasi, Chaukhamba Publication, 2000.

10. Acharya YT. Shushruta, Sushruta Samhita, Sharirasthana, 5/15, 7th ed. Varanasi: Chaukhambha Orientalia; 2002. p. 365.

11. Acharya YT. Shushruta, Sushruta Samhita, Sharirasthana, 5/22, 7th ed. Varanasi: Chaukhambha Orientalia; 2002. p. 366.

12. Sushrut sanhita: Dr. Bhaskar govind ghanekar vth edition, publication Motilal Banarasi Das, 1962.

13. garbh upnishad 2711 sanskrit text of garbha upnishad, Sanskrit documents Archives, Negi. World Journal of Pharmaceutical Research www.wjpr.net | Vol 10, Issue 4, 2021. ISO 9001:2015 Certified Journal | 9982009.

14. Umesh Chandra Pandey (editior) commentary Mitaksara of Vijnanaesvara on Yajnavalkya, Smriti of Yogisara Yajnavalkya, Pray, Yat, Varanasi: Chaukhamba Publication"s, 1967; 73.

15. Vaidya Jaymini Pandey, Nirmala Hindi commentary on Harita-Samhita Harita, Sharu Sthara Chapter 1, verse no. 17-19 first edition Varanasi: Chaukhamba visvabharat, 2010;

16. Sushrut, Illustrated Sushrut Samhita by K.R.Srikantha Murthy, Reprint edition, Chaukhamba Orientalia, Varanasi, 2010, page no.38-43

17. Health and pregnancy health centre, stages of pregnancy, WebMD, c2005-2017 (cited on 2017 Jan 4), available from www.m.webmd.com/baby /default.htm

18. Inderbir Singh, Human embryology, Tenth edition, Jaypee Brothers Medical Publishers (P) Ltd, New Delhi, 2015, page no 50-52.

19. Pregnancy-conception to 40 weeks, baby centre, c 1997-2017(cited on 2017 Jan 10), available from 
www.babycentre.co.uk./pregnancy-

calender

20. Cunningham; Leveno; Bloom, Williams Obstetrics Twenty fourth edition, McGrawHill education, New Delhi,2014, chaper 7, page no.129-32.

21. D C Dutta, edited by Hiralal Konar, Textbook of obstetrics, Sevwnth edition, New Central Book Agency (P) Ltd, Kolkata,2013,page no.50.

22. Irritability during pregnancy, Health, Kathryn Hatter, livestrong.com, c 2017 (cited on 2017 February 11), available from www.livestrong.com

23. Inderbir Singh, Human embryology, Tenth edition, Jaypee Brothers Medical Publishers (P) Ltd, New Delhi, 2015, page no. 152 .

How to cite this article: Mani K, Agrawal SA, Agrawal AS. Garbhavkranti and chronological evaluation of garbha: a review. International Journal of Research and Review. 2021; 8(7): 154-160. DOI: https:// doi.org /10.52403/ijrr.20210721 